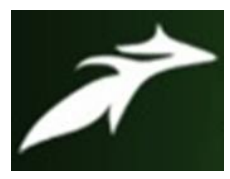

Lothungbeni Jami et al, International Journal of Advances in Agricultural Science \& Technology,

Vol.8 Issue.10, October-2021, pg. 84-93

ISSN: 2348-1358

Impact Factor: 6.057

NAAS Rating: 3.77

\title{
Adoption Behaviour Of Farmers Towards Off-Season Improved Cucumber Cultivation Practices In Wokha District Of Nagaland
}

\author{
Lothungbeni Jami' ${ }^{1}$ Dipak Kumar Bose ${ }^{2}$; Syed H. Mazhar ${ }^{3}$ \\ ${ }^{1}$ M.Sc. Ag. (Agricultural Extension and Communication), SHUATS (Prayagraj) \\ ${ }^{2}$ Associate Professor, Dept. of Agriculture Extension and Communication, SHUATS (Prayagraj) \\ ${ }^{3}$ Associate Professor, Dept. of Agriculture Extension and Communication, SHUATS (Prayagraj) \\ Author's e-mail: lothungjami123@gmail.com \\ DOI: 10.47856/ijaast.2021.v08i10.010
}

\begin{abstract}
Cucumber is one of the oldest vegetable crop grown widely throughout India as well as tropical and sub-tropical parts of the world. Nagaland, one of the eight states of the north east region is blessed with suitable agro climatic conditions and its soil is suitable for agriculture, where cucumber is grown in all the districts. Cucumber farmers in Nagaland have a lot of potential to venture out economically and establish successful adoption practices.

The study was conducted with the objectives to study the characteristics of cucumber growers, the extent of knowledge and determine the level of adoption by off season cucumber growers and to delineate the constraints faced by the respondents and to obtain their suggestions.

An interview schedule based on the study was prepared and data were collected with the help of interview schedule and processed through primary and secondary tables and statistical analysis. The present study was conducted in Baghty block of Wokha district of Nagaland. A total number of 120 respondents from 4 villages were selected using proportionate random sampling procedure. The respondents were contacted personally and interviewed.

The study revealed that majority of the cucumber belonged to middle aged group, educated between primary and high school level, had medium level of annual income with medium size of land holding. Majority of them had medium year of farming experience, use of sources of information and medium level of extension contact. It was observed that the majority of the respondents had medium level of adoption of recommended off season cucumber cultivation practices.
\end{abstract}

Keywords: Socio economic characteristics, adoption, Cucumber growers, Nagaland. 


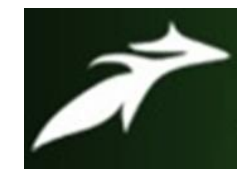

Lothungbeni Jami et al, International Journal of Advances in Agricultural Science \& Technology, Vol.8 Issue.10, October-2021, pg. 84-93

ISSN: 2348-1358

Impact Factor: 6.057

NAAS Rating: 3.77

\section{Introduction}

Off-season vegetable cultivation is the growing of vegetables by preponing and postponing the normal time of planting. The agricultural cropping season in India is generally divided into two main seasons. The kharif season is characterized by high temperatures, high rainfall and high humidity which generally lasts from July to September and the rabi season lasts from October to March. Cucurbitaceae is the largest family in vegetable kingdom and includes highest number of edible types.

Cucumber (Cucumis sativus L.) commonly known as 'kakadi' or 'khira' belonging to the family of Cucurbitaceae is one of the oldest vegetable crop grown widely throughout India as well as tropical and sub-tropical parts of the world. Cucumber is essentially a warm season grown mainly in tropical and subtropical regions. Generally long period of warm preferably dry weather and abundant sunshine are required. The temperature of $18^{\circ}-20^{\circ} \mathrm{C}$ is optimum. (Handbook on Farming for Nagaland)

Nagaland, one of the eight states of the north east region is blessed with agro climatic condition and soil suitable for agriculture. Nagaland is also one of the states where cucumber is grown in all the districts. Cucumber has been grown by tribals in Nagaland for centuries. It is one of the most important crops of the North Easthern states and Nagaland ranks fifth in area under cultivation and third in production. The districts of Mokokchung, Mon, Wokha, Kohima and Peren produce some of the best varieties of cucumber in the world. A wide variety of cucumber is grown in different parts of the state by different Naga tribe. The total area and production of cucumber in the state accounted for 727 ha and 13345 metric tonnes during 2018-19 (Statistical Handbook of Nagaland, 2020).

Cucumber farming unlike other farming requires specialized type of crop husbandry techniques and skill. The demand for cucumber is increasing as it fetches good price and income in a comparatively shorter period of time. This helps the cultivation in fulfilling his financial requirement at needy time.

The present study is therefore an attempt to understand about the potential characteristics of cucumber growing farmers. This may help extension personnel in boosting cucumber production by locating such farmers and by providing necessary facilities to them. 


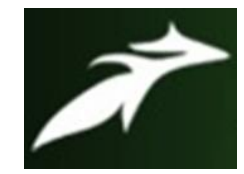

Lothungbeni Jami et al, International Journal of Advances in Agricultural Science \& Technology, Vol.8 Issue.10, October-2021, pg. 84-93

ISSN: 2348-1358

Impact Factor: 6.057

NAAS Rating: 3.77

\section{Materials and Methods}

The present study was conducted in Baghty block of Wokha district of Nagaland. A total number of 120 respondents from 4 villages were selected using proportionate random sampling procedure. Out of the 4 villages in Baghty block, 3 villages were selected through purposive sampling based on maximum area under cucumber crop.

Data was collected with the help of pre-structured interview schedule. The descriptive research design was used for the present research study.

The socio-economic variables selected for the study were age, education, family size, family type, occupation, land holding, annual income, farm experience, extension contact, mass media exposure and sources of information.

The study was undertaken under the following objectives.

i. To assess the socio-economic profile of the respondents

ii. To determine the level of adoption of off season cucumber production practices by the respondents

\section{Results and Discussion}

\section{Socio-economic characteristics of the respondents}

Table 1 revealed that majority $(63.33 \%)$ of the respondents belong to middle age group. $(40.83 \%)$ of the respondents had an educational qualification up to high school level. Majority $(92.50 \%)$ of the respondents was married and $74.16 \%$ had nuclear family. Majority (60\%) of the respondents had family size up to 5 members. Majority $(65.83 \%)$ of the respondents had medium level of income and medium (69.17\%) level of land holdings (2-6 acres). It was also found that majority $(54.16 \%)$ of the respondents had medium level of experience (10-20 years) in cultivation. Maximum number $(80.83 \%)$ of respondents had medium level of extension contact.

Majority $(79.17 \%)$ of the respondents never use the radio, majority $(49.17 \%)$ occasionally watch the television, majority (61.67\%) daily read the newspaper, it was found that majority (100\%) of the respondents never read journals or magazines. It was also found that majority $(64.17 \%)$ of the respondents get their source of information from frequent interaction with the progressive farmers, majority $(54.17 \%)$ sometimes interact with their neighbors and with their relatives $(64.17 \%)$ and majority $(55.84 \%)$ of the respondents frequently interact with their friends. 


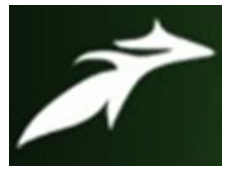

Lothungbeni Jami et al, International Journal of Advances in Agricultural Science \& Technology,

Vol.8 Issue.10, October-2021, pg. 84-93

ISSN: 2348-1358

Impact Factor: 6.057

NAAS Rating: 3.77

Table 1. Socio-economic profile of the respondents.

\begin{tabular}{|c|c|c|c|c|}
\hline S.no & $\begin{array}{l}\text { Independent } \\
\text { Variables }\end{array}$ & Category & Frequency & Percentage \\
\hline \multirow[t]{3}{*}{1.} & \multirow[t]{3}{*}{ Age } & \begin{tabular}{|l} 
Young (21-35) \\
\end{tabular} & 25 & 20.83 \\
\hline & & Middle Age (36-55) & 76 & 63.33 \\
\hline & & Old (Above 55) & 19 & 15.84 \\
\hline \multirow[t]{5}{*}{2.} & \multirow[t]{5}{*}{ Education } & Illiterate & 20 & 16.67 \\
\hline & & Primary & 41 & 34.17 \\
\hline & & High School & 49 & 40.83 \\
\hline & & Higher Secondary & 08 & 6.67 \\
\hline & & Graduate and above & $\mathbf{0 2}$ & 1.66 \\
\hline \multirow[t]{2}{*}{3.} & \multirow[t]{2}{*}{ Marital Status } & Married & 111 & 92.50 \\
\hline & & Unmarried & 09 & 07.50 \\
\hline \multirow[t]{2}{*}{4.} & \multirow[t]{2}{*}{ Type of family } & Nuclear Family & 89 & 74.16 \\
\hline & & Joint Family & 31 & 25.84 \\
\hline \multirow[t]{2}{*}{5.} & \multirow[t]{2}{*}{ Size of family } & Upto 5 members & 72 & 60.00 \\
\hline & & Above 5 members & 48 & 40.00 \\
\hline \multirow[t]{3}{*}{6.} & \multirow[t]{3}{*}{ Type of house } & Hut & 30 & 25.00 \\
\hline & & Cemented & 30 & 25.00 \\
\hline & & Semi-cemented & 60 & 50.00 \\
\hline \multirow[t]{2}{*}{7.} & \multirow[t]{2}{*}{ Occupation } & Farming & 66 & $\mathbf{5 5 . 0 0}$ \\
\hline & & Farming+Labour & 54 & 45.00 \\
\hline \multirow[t]{3}{*}{8.} & \multirow[t]{3}{*}{ Annual Income } & Low (Less than 60,000) & 28 & 23.33 \\
\hline & & Medium $(60,000-1,00,000)$ & 79 & 65.83 \\
\hline & & High (Above $1,00,000$ ) & 13 & 10.84 \\
\hline
\end{tabular}




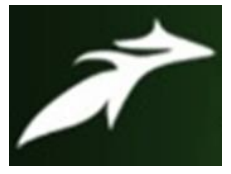

Lothungbeni Jami et al, International Journal of Advances in Agricultural Science \& Technology,

Vol.8 Issue.10, October-2021, pg. 84-93

ISSN: 2348-1358

Impact Factor: 6.057

NAAS Rating: 3.77

\begin{tabular}{|c|c|c|c|c|c|}
\hline \multirow[t]{3}{*}{9.} & \multirow{3}{*}{$\begin{array}{ll}\text { Total Land } \\
\text { Holdings }\end{array}$} & \multicolumn{2}{|l|}{ Low $(<2$ acre $)$} & 25 & 20.83 \\
\hline & & \multicolumn{2}{|l|}{ Medium (2-6 acre) } & 83 & 69.17 \\
\hline & & \multicolumn{2}{|l|}{ High (>6 acre) } & 12 & 10 \\
\hline \multirow[t]{3}{*}{10.} & \multirow{3}{*}{$\begin{array}{l}\text { Farming } \\
\text { experience }\end{array}$} & \multicolumn{2}{|l|}{ Below 10 years } & 43 & 35.84 \\
\hline & & \multicolumn{2}{|l|}{$10-20$ years } & 65 & 54.16 \\
\hline & & \multicolumn{2}{|l|}{ Above 20 years } & 12 & 10.00 \\
\hline \multirow[t]{3}{*}{11.} & \multirow[t]{3}{*}{ Extension contact } & \multicolumn{2}{|l|}{ Low } & 16 & 13.33 \\
\hline & & \multicolumn{2}{|l|}{ Medium } & 97 & 80.83 \\
\hline & & \multicolumn{2}{|l|}{ High } & 07 & 5.84 \\
\hline \multirow[t]{12}{*}{12.} & \multirow{12}{*}{$\begin{array}{ll}\text { Mass media } \\
\text { exposure }\end{array}$} & \multirow[t]{3}{*}{ Radio } & Daily & $\mathbf{0}$ & $\mathbf{0}$ \\
\hline & & & Occasionally & 25 & 20.83 \\
\hline & & & Never & 95 & 79.17 \\
\hline & & \multirow[t]{3}{*}{ Television } & Daily & 20 & 16.67 \\
\hline & & & Occasionally & 59 & 49.17 \\
\hline & & & Never & 41 & 34.16 \\
\hline & & \multirow{3}{*}{ Newspaper } & Daily & 74 & 61.67 \\
\hline & & & Occasionally & 14 & 11.67 \\
\hline & & & Never & 32 & 26.66 \\
\hline & & \multirow[t]{3}{*}{ Magazines/Journals } & Daily & $\mathbf{0}$ & $\mathbf{0}$ \\
\hline & & & Occasionally & $\mathbf{0}$ & $\mathbf{0}$ \\
\hline & & & Never & 120 & 100 \\
\hline \multirow[t]{4}{*}{13.} & \multirow{4}{*}{$\begin{array}{l}\text { Sources of } \\
\text { information }\end{array}$} & \multirow{3}{*}{$\begin{array}{l}\text { Progressive } \\
\text { Farmers }\end{array}$} & Frequently & 77 & 64.17 \\
\hline & & & Sometimes & 28 & 23.34 \\
\hline & & & Rarely & 15 & 12.50 \\
\hline & & & & & \\
\hline
\end{tabular}




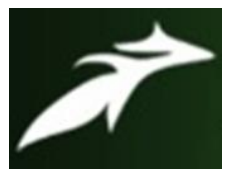

Lothungbeni Jami et al, International Journal of Advances in Agricultural Science \& Technology,

Vol.8 Issue.10, October-2021, pg. 84-93

ISSN: 2348-1358

Impact Factor: 6.057

NAAS Rating: 3.77

\begin{tabular}{|l|l|l|l|l|l|}
\hline \multirow{2}{*}{} & Neighbours & Frequently & $\mathbf{3 0}$ & $\mathbf{2 5}$ \\
\cline { 3 - 5 } & & Sometimes & $\mathbf{6 5}$ & $\mathbf{5 4 . 1 7}$ \\
\cline { 3 - 5 } & & Rarely & $\mathbf{2 5}$ & $\mathbf{2 0 . 8 3}$ \\
\cline { 3 - 5 } & Relatives & Frequently & $\mathbf{1 5}$ & $\mathbf{1 2 . 5 0}$ \\
\cline { 3 - 5 } & & Sometimes & $\mathbf{7 7}$ & $\mathbf{6 4 . 1 7}$ \\
\cline { 3 - 5 } & & Rarely & $\mathbf{2 8}$ & $\mathbf{2 3 . 3 4}$ \\
\cline { 3 - 5 } & \multirow{2}{*}{ Friends } & Frequently & $\mathbf{6 7}$ & $\mathbf{5 5 . 8 4}$ \\
\cline { 3 - 5 } & & Sometimes & $\mathbf{4 7}$ & $\mathbf{3 9 . 1 7}$ \\
\cline { 3 - 5 } & & Rarely & $\mathbf{6}$ & $\mathbf{5 . 0 0}$ \\
\cline { 3 - 5 } & & &
\end{tabular}

\section{Adoption behavior of the respondents}

The results presented in Table 2 revealed that majority (75\%) of the respondents fully adopted the recommended varieties followed by suitable planting time $(89.17 \%)$, field preparation (86.67\%), method of sowing (82.50\%), manures and fertilizers (26.67\%), harvesting $(77.50 \%)$ and yield per hac $(72.59 \%)$ with respect to cucumber cultivation whereas most $(58.34 \%)$ of the respondents partially adopted spacing, recommended seed rate $(18.33 \%)$, inter cultivation $(20 \%)$, weed management $(26.67 \%)$. It was found that majority $(59.17 \%)$ of the respondents had not adopted the pest control and (47.50\%) respondents had not adopted disease control of the recommended off season cucumber cultivation.

The main reasons of non adoption of the recommended practices were due to inadequate knowledge and exposure of the recommended practices of off season cucumber cultivation. High percentage of non adoption of recommended practices was mainly attributed to their low knowledge and skill with respect to these practices. In absence of the required exposure farmers continued with their traditional practices with more confidence in production as well as management. 


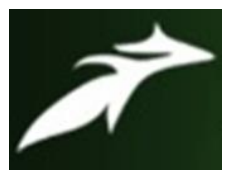

Lothungbeni Jami et al, International Journal of Advances in Agricultural Science \& Technology,

Vol.8 Issue.10, October-2021, pg. 84-93

ISSN: 2348-1358

Impact Factor: 6.057

NAAS Rating: 3.77

Table 2:-Distribution of the adoption level of the respondents about recommended off season cucumber cultivation practices.

\begin{tabular}{|c|c|c|c|c|c|c|c|}
\hline \multirow{3}{*}{ Sn } & \multirow{3}{*}{ Statements } & \multicolumn{6}{|c|}{ Adoption level } \\
\hline & & \multicolumn{2}{|c|}{ Fully adopted } & \multicolumn{2}{|c|}{$\begin{array}{l}\text { Partially } \\
\text { adopted }\end{array}$} & \multicolumn{2}{|c|}{ Not adopted } \\
\hline & & $\mathbf{f}$ & $\%$ & $\mathbf{f}$ & $\%$ & $\mathbf{f}$ & $\%$ \\
\hline 1 & Varieties recommended & 90 & 75.00 & - & & 30 & 25 \\
\hline 2 & Planting/ sowing time & 107 & 89.17 & - & & 13 & 10.83 \\
\hline 3 & Field preparation & 104 & 86.67 & 16 & 13.33 & - & \\
\hline 4 & Method of sowing & 99 & 82.50 & 12 & 10 & 9 & 7.50 \\
\hline 5 & Manures and fertilizers & 32 & 26.67 & 27 & 22.50 & 61 & 50.83 \\
\hline 6 & Spacing & 25 & 20.83 & 70 & 58.34 & 25 & 20.83 \\
\hline 7 & Seed rate & 98 & 81.67 & 22 & 18.33 & 10 & 8.33 \\
\hline 8 & Inter cultivation & 20 & 16.67 & 24 & 20 & 76 & 63.33 \\
\hline 9 & Irrigation & 76 & 63.33 & 27 & 22.50 & 17 & 14.17 \\
\hline 10 & Weed management & 76 & 63.33 & 32 & 26.67 & 12 & 10 \\
\hline 11 & Pest control & 40 & 33.33 & 9 & 7.50 & 71 & 59.17 \\
\hline 12 & Disease control & 43 & 35.83 & 20 & 16.67 & 57 & 47.50 \\
\hline 13 & Harvesting & 93 & 77.50 & 22 & 18.33 & 5 & 4.17 \\
\hline 14 & Yield per hac & 87 & 72.59 & 16 & 13.33 & 17 & 14.17 \\
\hline
\end{tabular}




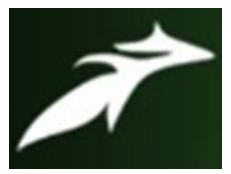

Lothungbeni Jami et al, International Journal of Advances in Agricultural Science \& Technology,

Vol.8 Issue.10, October-2021, pg. 84-93

ISSN: 2348-1358

Impact Factor: 6.057

NAAS Rating: 3.77

Table 3: Distribution of the respondents based on the adoption towards off season cucumber cultivation.

\begin{tabular}{|l|l|l|l|l|l|}
\hline Sn & Category & Frequency & Percentage & Mean & SD \\
\hline 1 & Low $(<30)$ & 16 & 13.33 & \multirow{3}{*}{32.8} & \multirow{2}{*}{2.9} \\
\hline 2 & Medium $(30-35)$ & 85 & 70.83 & & \\
\cline { 1 - 2 } 3 & High $(>35)$ & 19 & 15.84 & & \\
\hline & Total & 120 & $100.00 \%$ & & \\
\hline
\end{tabular}

Table 3 revealed that $70.83 \%$ of respondents were having medium level of adoption followed by $15.84 \%$ of respondents having high level of adoption whereas $13.33 \%$ of respondents were having low level of off season cucumber crop.

Similar findings were also reported by Reddy et al., (2018) and Venkataramulu et al., (2010)

\section{Association of independent variable with the adoption of recommended practices of off season cucumber cultivation.}

Table 4: Association of independent variables with the adoption of recommended practices of off season cucumber cultivation

\begin{tabular}{|l|l|l|}
\hline S.No & \multicolumn{1}{|c|}{ Variables } & Pearson's correlation coefficient \\
\hline 1 & Age & $0.185^{*}$ \\
\hline 2 & Education & $0.140 \mathbf{~ N S}$ \\
\hline 3 & Marital status & $0.024 \mathbf{~ N S}$ \\
\hline 4 & Type of family & $0.141 \mathbf{~ N S}$ \\
\hline 5 & Family size & $0.056 \mathbf{~ N S}$ \\
\hline 6 & Type of house & $0.131 \mathbf{~ N S}$ \\
\hline 7 & Occupation & $0.205^{*}$ \\
\hline 8 & Land holding & $0.131 \mathbf{~ N S}$ \\
\hline 9 & Annual income & $0.202^{*}$ \\
\hline
\end{tabular}




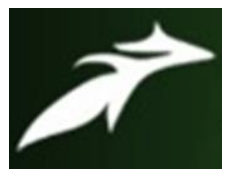

Lothungbeni Jami et al, International Journal of Advances in Agricultural Science \& Technology, Vol.8 Issue.10, October-2021, pg. 84-93

ISSN: 2348-1358

Impact Factor: 6.057

NAAS Rating: 3.77

\begin{tabular}{|l|l|l|}
\hline 10 & Farming experience & $0.016 \mathrm{NS}$ \\
\hline 11 & Extension contact & $0.187 *$ \\
\hline 12 & Mass media exposure & $0.102 \mathrm{NS}$ \\
\hline 13 & Source of information & $0.127 \mathrm{NS}$ \\
\hline
\end{tabular}

$*=$ Significant at $\mathrm{p}=0.05 \%, \mathrm{NS}=$ Non Significant

The result of correlation analysis in above table 4 revealed the significance and non-significance of the socio- economic profile of the people and their adoption behavior towards off season cucumber growers.

Table 4 revealed that independent variables like age, occupation, annual income, extension contact are significantly associated with adoption of off season cucumber growers. It may be inferred that respondent's age, their occupation, income and having high extension contact had relatively higher level of adoption of recommended off season cucumber cultivation practices. Further, the variables education, marital status, type of family, family size, type of house, land holding, farming experience, mass media exposure and source of information was found to be non significant.

\section{Conclusion}

It was concluded that majority of the respondents were middle aged people, had education up to high school level and majority are married. Most of the respondents had a nuclear family and most of them lived in semi-cemented house. Majority of the respondents had agriculture as their occupation and majority of them had farming experiences of above 20 years. A large number of the respondents had medium level of income.

It was found that majority of the respondents had medium (70.83\%) level of adoption. Variables like age, occupation, annual income, extension contact are significantly associated with adoption of off season cucumber growers. While education, marital status, type of family, family size, type of house, land holding, farming experience, mass media exposure and source of information was found to be non significant.

The researcher hopes that this research study would be highly useful in understanding the personal, socio-economic and psychological characteristics of the cucumber growers with their level of adoption of the improved cultivation practices technology. 


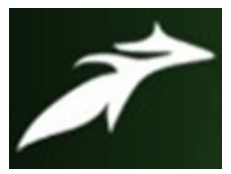

Lothungbeni Jami et al, International Journal of Advances in Agricultural Science \& Technology,

Vol.8 Issue.10, October-2021, pg. 84-93

ISSN: 2348-1358

Impact Factor: 6.057

NAAS Rating: 3.77

\section{References}

[1]. Bhajipale, D.D., Kharde, P.B and Karangami, R.S (2020). Knowledge of improved cultivation practices of watermelon by the respondents. International Journal of Chemical Studies, 8(1): 1157-1160.

[2]. Department of Economics \& Statistics (2018) Statistical Handbook of Nagaland. Directorate of Economics and Statistics, Government of Nagaland, Kohima. https://statistics.nagaland.gov.in/storage/statistical data/2018/941601130581.pdf

[3]. Jha, K.K and Das, R (2019). Adoption of recommended production technology by chilli growers in Tripura. Indian Journal of Extension Education Vol. 55, No. 3, (117-122)

[4]. Melkeri, A.K and Mazhar, S.H. (2018) Relationship between Profile Characteristics with Knowledge and Adoption of Transplanting Method of Pigeon Pea Cultivation Practice. Economic Affairs, 63(2) : 299-305.

[5]. Nayan, R. and Mazhar, S.H. (2016) Adoption Behaviour of Brinjal (Solanum melongena L) Growers in Nawada Block of Nawada District of Bihar. International Journal of Engineering Technology, Management and Applied Sciences., 4(9) : 44-48

[6]. Ngadong, A. and Longkumer, J. (2018) Knowledge and adoption level of large cardamom cultivators of Anjaw District, Arunachal Pradesh. Indian Research Journal of Extension Education 18(1) pp. 96-100.

[7]. Pongener, $\mathbf{S}$ and Jha, K. K (2020). Entrepreneurial behaviour of off season cucumber growers: an analysis in Mokokchung district, Nagaland. 20(1) pp. 763-768.

[8]. Reddy, V., Wakle, P.K., Koshti, N.R. and Tingrae, A.S. (2018). Extent of adoption and utilization of sources of information in recommended chilli production technology. Int.J.Curr.Microbiol.App.Sci., 7(2): 3220- 3227 .

[9]. Singh, N.P., Bhardwaj, A.K., Kumar,A and Singh, K.M. (2017) Modern Technology on Vegetable Production. International Book Publishing Co., Lucknow, India, 228-234.

[10]. Tangjang, A. and Sharma, A. (2018). Problem Faced by the Large Cardamom Growers during Production and Marketing: A Case Study of Tirap District of Arunachal Pradesh, India. Int.J.Curr.Microbiol.App.Sci.2018. 7(5): 2561-2573

[11].Thombre, B.M., Atar, R.S. . and Suradkar, D.D. (2013). Knowledge of recommended grape cultivation practices by the grape growers. Agric. Update, 8(1\&2): 115-118.

[12]. Venkataramulu, M., Hanchinal, S.N., and Hirevenkanagoudar, L.V.(2010) Adoption of improved cultivation practices among chilli growers. Karnataka J. Agric. Sci., 22(5) : (722-725) 2010 